\title{
The Creation of Female Characters in Works of Art of the Uighur Classics
}

\author{
Aida Abdrakhmanovna Mashurova ${ }^{1}$, Toygan Ospankyzy Izim ${ }^{2} \&$ Gulnara Yusupovna Saitova ${ }^{1}$ \\ ${ }^{1}$ Kazakh National Academy of Arts named after T. Zhurgenov, Kazakhstan \\ ${ }^{2}$ Kazakh National University of Arts, Tauelsizdic ave., Astana, Kazakhstan \\ Correspondence: Aida Abdrakhmanovna Mashurova, Panfilov str., 127, Almaty, 050000, Kazakhstan.
}

\author{
Received: February 10, 2015 Accepted: April 26, 2015 Online Published: July 30, 2015 \\ doi:10.5539/ass.v11n19p159 URL: http://dx.doi.org/10.5539/ass.v11n19p159
}

\begin{abstract}
The volume of unique, preserved up to date information on the history of the well-known and outstanding women's lives, whose destinies were brilliant and dramatic, as written down by the eyewitnesses and participants of events, has created a certain base for the research initiation directed at the development of problems on reenacting their images in modern professional musical, theatrical art and also cinema. The article, based on historical data, deals with legendary female epos - Iparkhan, Maimkhan, Nazugum. The movies, "Year of the Dragon" filmed at Kazakhfilm and "Nozugum", filmed at Uzbektelefilm, are analyzed.
\end{abstract}

Keywords: female, heroic images, Uighur people, East Turkestan, fighter

\section{Introduction}

Historical and cultural changes occurred at the boundary of the XXth and the XXIst centuries, during fighting for independence and formation of the sovereign states of the former Soviet Union Republics, including Kazakhstan. One of the major tasks facing the Kazakhstan public policy is the revival of the huge spiritual and cultural potential created by the people through many centuries.

Modern art quests for national traditions and cultural heritage set certain research tasks for art critics which are aimed at the identification of new tendencies in the field of art, in particular cinema studies, being integral part of the world art culture.

Certainly, it is almost impossible to cover and reveal the innovative ideological and art essence of motion picture art, its multinational nature within one article. Moreover, the main objective of the paper is the definition of a problem of creating a heroic female character in works of art of the Uighur classics. This subject remains topical at all times.

Most often, people associate the concepts of the hero and a heroic deed with a priority of a strong half of mankind - men. But there is a set of examples of force, courage and heroism in women of the different people during different eras who sacrificed their lives both in the class struggle and in struggle for liberation of the people against overseas enslavers.

The heroic sagas and epic poems created by the people praised beauty, wisdom, and fidelity of women, their courage and military valor. One of such heroines is "Tomiris" (about 570-520 BC) - the queen of Massagets, according to researchers, the Scythian nomadic cattle breeding people. The history of Tomiris and her victories over Cyrus was well-known in a classical antiquity and became a legend; such antic writers as Herodotus, Polyaenus, Cassiodorus, and Jordanis wrote about her, about her deeds. The same things could be said about the heroine France Joan of Arc (about 1412-31) who headed "the fight of the French people against English aggressors" (The Great Russian Encyclopedia, 1998, p. 396). In their works, the great Uzbek poetesses Zebunnissa (1639-1706), Dilshod-Barno (1800-1905), Anbar-atyn (1870-1515) praised "humanity, love to life and the nature"; the statement about disagreement with the conditions dominating at that time trampling on freedom of the person" and huge love for the country". Their verses were quoted among the people, handing down the following: "A person shall listen to reason, cherish the Homeland as the second mother" ("The selected lyrics of the East", 1983, 3-4). The glorious women of the Kazakh people who had given lives for the Homeland in the years of World War II, such as the Heroes of the Soviet Union Manshuk Mametova (1922-1943) and Aliya Moldagulova (1925-1944). The history of the Uighur people has preserved the names of heroic women such as 
Iparkhan (the middle of the XVIII century), Maimkhan (XIX century), Nazugum (1800-1830), Rizvangul (1944).

The volume of unique, preserved up to date information on the history of the well-known and outstanding women's lives, whose destinies were brilliant and dramatic, as written down by the eyewitnesses and participants of events, has created a certain base for the research initiation directed at the development of problems on reenacting their images in modern professional musical, theatrical and film art.

We have to agree with B.M. Nemensky who writes that "art is the most important means of familiarizing of the person with universal values through one's own internal experience, through personal emotional experiences ... the layer of the most difficult tasks and phenomena of art culture is immense - this layer has come a long way through centuries. It is a vast circle of knowledge. Or rather understanding through "re-experiencing the experience of the ancestors". And this unusual knowledge demands for a "guide" - a person who would cleverly, tactfully, and gradually lead you into the world of art culture. The world where every floor of the building you are to live in is the venue of your nation's culture" (Nemenskiy, 1987, p. 215).

In our article, we will try to become that "guide", and basing on historical data, lead you into "the world of art culture" where legends of the Uighur beauties were made and where they were admired and taken pride of.

However it is possible only on condition of solving the following tasks:

- Studying of peculiarities of the Uighur people historical development;

- Research on creation of female heroic images on the basis of the Uighur national works on a theatrical stage of Kazakhstan;

- The analysis of motion picture production such as, "Year of the Dragon", Kazakhfilm and "Nozugum" made in Uzbektelefilm.

\section{Methodology}

The following complex of research methods was used for the solution of objectives:

- Theoretical and art analysis;

- The analysis of scientific literature;

- Benchmarking study based on relation of literary, scenic work and cinematography.

- A method of scientific projection for definition of objectives.

Obviously only on this basis it is possible to reveal a subject problem - "An embodiment of female images (Iparkhan, Maimkhan, Nazugum) in works of art of the Uighur classics".

Analyzing "the Empire of Turkic peoples", the academician, professor, the doctor of historical sciences, the Doctor of Philosophy R. Rakhmanaliyev writes that "The Uighurs are well-known in the Chinese history. These are descendants of Gaodju which were natives of group of "Hunn" (Rakhmanaliyev, 2013, p. 160). We shall not study in detail the Uighur ethno genesis since it is not a main objective. However, let's note that "the historical, linguistic, ethnographic, archaeological data which are saved up by modern science give the grounds for a conclusion that the Uighur people are a fusion of two ethnic substrata: ancient settled population of East Turkestan and the nomadic Orkhon-Yenisei Uighurs who finally settled in this territory after the fall of the Uighur khanate" (Saitova, 2011, p. 15). Since the period of their appearance in history, up to the XIV century and despite rises and recessions in certain historical periods "our ancestors and related tribes and nations, created the great, strong, rich and powerful states during quite a considerable interval of time, and had advanced culture, and thereby brought an indelible contribution in universal culture and history" (Uighurs, 2008, p. 4).

Along with the aforesaid, we shall remind that throughout many centuries the Uighur people also combated for political independence. Besides as noted by L. N. Gumilev, "natural belligerence in the Uighurs did not disappear from abstentionism and prayers" (Gumilev, 1993, p. 382). Probably "natural belligerence" stayed with women also. During the periods of territory liberation from foreigners, they would take sword in hand and fight for the Homeland.

For example, the granddaughter of Kashgar mufti Appak-Hodzha and the spouse to the well-known Kashgar Belogorets hodzha - Khan-Hodzha, Iparkhan participated in some battles against the Qin troops, and after the death of the husband, in about 1760 was captured and sent to Beijing, to the emperor to Qianlong, to his harem. Captivated by her beauty and seeking mutual love, the emperor builds a miniature native settlement, including a mosque in front of her windows. 
The materials collected by the doctor of historical sciences, V. Kuznetsov notes the special attitude of the emperor towards Iparkhan, who was called Xiang-fei meaning "the fragrant concubine". The author writes: "Caring so she feels more like home then in the foreign land, the emperor ordered oil paintings of Kashgaria from the Milanese Giuseppe Castiglione who was then stationed in Beijing within Lazarists monks. ... Not a single concubine ever received such luxury that Xiangfei's tower would have. ... All of the Hong Li's efforts were in vain. She died, having committed suicide in 1788, and by the emperor's order 120 servants delivered her body to Kashgaria where it was buried in the patrimonial tomb, which remains even today.

In the memory of the Uighur people, Iparkhan remained not only the fighter for freedom, but also the faithful wife to the husband since she committed suicide, not willing to become the wife of the Chinese emperor.

Today, two portraits of Iparkhan painted by Giuseppe Castiglione are of historical value.

Jin Yong mentions Xian-fei in his novel - "The book and the sword - gratitude and revenge".

Based on the story about "the fragrant concubine" Xian-Fei, the play "Iparkhan - Xian-Fei" was written and staged in Kyrgyz Drama theater (2008) by the Kyrgyz playwright and director Zhanysh Kulmambetov.

In the article "The Fragrant Concubine in a Gold Imprisonment", the author of the play Zhanysh Kulmambetov reveals the reasons of the interest to a love story of the Chinese emperor and the proud rebellious daughter of the Uighur people Iparkhan.

Let's pay attention that, for the first time, the Uighur subject began to appear on a stage of the Kyrgyz Theater.

In 2008, the play "Iparkhan" by M. Kibirov, K. Abdrusulov, I. Dzhalilov is staged at the Uighur theater - the world's only professional theater, opened in 1934 on the territory of Kazakhstan in the city of Alma-Ata.

The premiere of the musical drama "Iparkhan", sparked keen interest within the Uighur intellectuals and among the audience. Interest is stipulated by the fact that the director of the theater M. Izimov together with the designer P. Ibragimov and the ballet master G. Saitova managed to take out this performance from high civic stands, and tried to recreate one of the pages of history of the Uighur people in fight against the Manchurian-Chinese aggressors. Certainly, the central role is played by an image of Iparkhan played by a young actress of the theater S. Sharipova. In a scene of reminiscence of the native land, Iparkhan-S.Sharipova turns from the proud and courageous girl-soldier into the humble heroine. Possessing a fine voice, S. Sharipova transfuses pain and suffering, love and dream of happiness of the people with lyricism and romantic enthusiasm.

The motif of legendary heroines, first of all, could be found in works of the Uighur literature classics: the XIXth century is the century marked by the outstanding Uighur poet Bilal Nazym (1825-1900). His life was inseparably linked "with distressful destiny of the native people" (Khamrayev, 1996, p. 124). He not only created a number of lyrical verses and poems, but was himself the participant of the revolt, that occurred in 1864-1867. Therefore, it is noteworthy that the poem "War of Muslims against Chinese" written by Bilal Nazym "is strictly documentary" (Nazym, 2011, p. 4).

Among the Uighur classics of the XXth century, the special spot belongs to the writer, playwright, screenwriter, translator Ziya Samadi (1914-2000). The participant of anti-Kuomintang revolt (1944), the Minister of Cultural Affairs of Xinjiang Uighur Autonomous Region (1950-1958) emigrated to Kazakhstan (1961) where he continued his creative work. He is the author of the historical novel "Maimkhan", the novel "Secrets of Years", plays such as "Iparkhan", "Inside the Chinese zindans", "Disturbing Minutes", "Crash of Tyranny", movie essay "On the Ili River Banks", the musical drama "Gerip and Sanam" and others.

The first Uighur professional composer, the people's artist of the USSR, Professor Kuddus Kuzhamyarov (1918-1994) personalized the characters of Nazugum and Rizvangul in the significant large musical pieces as the opera and the symphonic poem.

Let's return to works of literary classics of different eras. So, the XIXth century - the century of continuous armed struggle of the Uighur people against "a ruling class of old China and against oppression of the feudal lords". The Doctor of Philology, professor M. K. Khamrayev "stretched this (the Uighur - M. A.) poetic thread from the past and interwove it into the fabric of universal culture" (Ganichev, 2011, p. 194). While studying the literary works of Bilal Nazym, he writes: "Bilal Nazym lived in the time, difficult for the Uighur people. ... It is enough to specify that within the XIXth century seven large revolts $(1814,1816,1825-27,1830,1847,1857$, 1864) occurred in Xinjiang and were directed against domination of Manchurian feudal lords. Uighur peasantry who addressed anti-feudal requirements, was the main driving force of these revolts" (Khamrayev, 1996, p. 126).

The Russian scientist N. N. Pantusov who had a chance to meet the classic of the Uighur poetry significally contributed to the studying of works of B. Nazym. Nikolay Nikolaevich Pantusov noted that "Mullah Bilyal who 
took part both in the fight against Chinese and in the skirmish with the Russian troops trying to capture the Iliyskiy region, was more than 54 years of age. Nowadays he performs a duty of the imam at one of Ghulja mosques, and in his spare time he maintains continuous re-writing of compositions and occupies the position of the mullah-clerk" (Pantusov, 1811, p. 4).

Owing to Bilal Nazym, his "Stories about Nazugum", based on real events of "Jahangir's Revolt", the history knows about tragic destiny of the Kashgar woman Nazugum, about her dedicated fight for freedom of her native land. The original name of the heroine - Hanipagul. Nazugum was a daughter of Avutulla - the commandant of the Artush district. The first translator of the story into Russian, the Uighur history expert, N. N. Pantusov depicted the appearance of Nazugum: she "was thin, wheat-colored, dark eyes, dark-browed. The people named her Nazugum (gentle) for her gentle look and figure" (Pantusov, 1909, p. 220). Nazugum "was intelligent and had the poetic gift. ... besides her parents, she had a brother who was taken prisoner together with her, and also the husband and the three-year-old son whom, apparently, the Manchurians had killed. News about the death of the husband and the three-year-old son, killed before the eyes of villagers, did not break the fragile woman, they made her even stronger (Khamrayev, 1996, p. 129).

Unfortunately, just as many Uighur girls, the young woman were captured. She was sold against her will to the rich merchant Shi Sang. Not willing to become the concubine, Nazugum decides to escape. For 12 days she was hiding from prosecution. These facts were described in her songs. Nazugum failed in her numerous escapes and, eventually, she was caught. It happened in a mountain cave near "Ketmen" myalisi. Having surrounded the cave where Nazugum hid from all directions, Manchurians held a siege for a long time. However in time they realized that the woman could stand starvation for a long time and they decided to smoke her out. They blocked every exit from the cave and started burning hay. The caustic smoke soaked up in all openings between stones. Nazugum could not stand this challenge and ran out of the cave. As soon as she exited, she was grabbed and chained by the Chinese. She spent 82 days in prison, inside the pit of Ghulja city. There are several versions to the execution of Nazugum. According to one of them, fearing the disturbances, the authorities decided to carry out execution in secret; by another version, she was executed publicly. No matter the execution, Nazugum remained freedom-loving, proud, and unsubdued in the hearts of the people.

The works of Kuddus Kuzhamyarov, the author of the first Uighur opera has marked a qualitatively new stage in development of the Uighur national culture. "As the artist I see my goal in praising my people and pages of its history. When setting the goal to praise the destiny of the people. Each artist, first of all, has to enrich the knowledge: to study culture, literature, history, and heritage of the people. There are pages, which will surely interest you, and you will reflect: what is necessary to discover and embody it in your work. I always aspired to it ... To create a new piece of music, I have to represent, re-embody the wealth of my people...", - once said Kuddus Kuzhamyarov (Kirina, \& Khasanova, 2003, p. 15).

The symphonic poem "Rizvangul" written in his youth (1950) became a large creative victory. Studying history of the people, the amateur composer learns about a feat of the girl Rizvangul fighting against Kuomintang regime (1944). Under impression and defining dramatic art and structure of work, he composes the three-part symphonic poem where he reveals "images of fight, death of Rizvangul, crying of the people and its unbending will to a victory over enemies" (Kirina, 1994, p. 64).

The premiere took place in Moscow in all-Union screening of the Soviet composers' works. Symphonic work of K. Kuzhamyarov, student of the Kazakh State conservatory, was performed by the State symphonic orchestra of the USSR under the leadership of the young Uighur conductor Gaziz Dugashev (later the people's artist of KAZSSR). In 1951 K. Kuzhamyarov was awarded the State USSR award for the symphonic poem "Rizvangul".

"Nazugum" opera is the top one of the early works of the composer and the first Uighur-topic opera.

While devoting the dissertation research to processes of formation and development of the Uighur musical drama and analyzing works of the composer K. Kuzhamyarov, the musicologist R. K. Chasanoff's, traces all stages of transition of a traditional folklore monophony to symphonic style which found the brightest expression in his operas.

Exploring the development of versions in the musical drama "Nazugum", the author writes in his work: "It is symptomatic that genre options of this work demonstrate evolution of a musical and drama genre into the opera: 1925 - the drama play with music spots, 1954 - the musical drama, 1956 - the opera" (Khasanova, 1986, p. 18).

Written in 1925, the drama play "Nazugum" generally consisted of favourite songs and melodies about Nazugum. Participants of amateur talent group including masters of national folk art, authors of performances, one-act plays such as A. Rozybakiyev, K. Ruziyev, Z. Bashiri, N. Abdusamatov would not only along quote national 
folklore, but also displayed the heroic past of the Uighur people.

In 1954, Kuddus Kuzhamyarov composes musical acts for Kadyr Khasanoff's play "Nazugum". The musical drama appeared on a scene of the Uighur Theater.

"The musical drama "Nazugum" played a significant role in the process of genre development in preparation of the ground for emergence of a new genre in the Uighur musical culture - opera" (Khasanova, 1986, p. 20). Authors K. Khasanoff (librettist) and K. Kuzhamyarov (composer) did not adhere to historical details and composed the opera in a lyric and heroic genre. The opera was in Kazakh language. Therefore, the premiere of the opera took place owing to the staff of the Kazakh academic opera and Ballet Theater named after Abai. The first performer of Nazugum character was Roza Dzhamanova, the honored actress of the USSR. She managed to create a lyric and dramatic character where she discovered not only the "patriotic heroine", but also "the loving, womanly nature".

In 1969, the chief director of the Uighur Theater S. R. Bashoyan invites K. Kuzhamyarov and K. Khasanoff to stage the musical drama "Nazugum" in the new edition. Kuddus Kuzhamyarov's music now sounded heroic and patriotic. In 1980 it received the new music written by one of his students, H. Z. Setekov (Saitova, 2011, p. 76).

It would be desirable to remind that the close collaboration of the composer K. Kuzhamyarov and the creative staff of the Uighur Theater lasted throughout all his life. As music composer K. Kuzhamyarov was the coauthor of musical performances of the Uighur Theater such as "Sadyr Palvan" by A. Makhpirov (1958), "The Daughter of Kashgaria" ("Kashgar kyza") by S. Mukanova (1973). Its symphonic works "Meshrep", "Takla Makan", "Margul" for chamber orchestra, "The poem about a Dutar" was played by actors of the Uighur Theater, by folklore "Nava" ensemble and symphonic orchestras of Conservatory and Opera Theater. Indisputable professional skill of the composer, an organic combination of national identity in his music, and achievements of modern European musical culture opened additional opportunities in disclosure of depth of dramatic nature of these works for the State Republican Uighur Theater of the musical comedy.

A very plausible fact that the issue of heroism, history of the entire nations, in this case Uighurs is reflected not only in literary and musical creativity but is also depicted on the film.

It is known that "the interest to national plots and to national literature not only performed well, but also pushed the cinema on the way of art" (Abikeeva, 2006, p. 149). The doctor of art history, the film expert, R.N. Yurenev reveals ideological and art essence of screen art, its multinational character and pays special attention to one of factors which matters in the international cinematography. "National art, - the author writes, - is born when national character and its spirit is expressed. And, having expressed it and embodied it in cinema figurativeness, that spirit takes out national character, events of life of the people to the international scene" which then "finds the international value" (Yurenev, 1986, p. 149).

The author of the book "Building Nation in Kazakhstan", the film expert, the film critic and the doctor of art history Gulnara Abikeeva explores the "films of various eras: "thaw" 1, the "reconstruction" 2, first films of independence and the modern period shot by directors from Kazakhstan, Kyrgyzstan, Uzbekistan, Tajikistan and Turkmenistan" ..." (Abikeeva, 2006, p. 9), and brings up questions of interrelation of a national identity development and the cinema. In chapter 1 of the book, G. O. Abikeeva includes four articles with one of which being "An image of the woman in the cinema of Central Asia". In this article, the author "considers transformation of female characters since the beginning of emergence of a cinema in our region (Kazakhstan A.M.) - Since the 1930s years till today" (Abikeeva, 2006, p. 11). Unfortunately, G. O. Abikeeva does not consider such films as "Year of the Dragon" and "Nozugum" which showed the legendary female characters Maimkhan and Nazugum shot in "Kazakhfilm" and "Uzbektelefilm" studios. Certainly, duly reasons preceded that fact. First, it is not possible to capture all movies representing cinematography of Central Asia. Secondly, this is our subjective opinion, films simply occured in between the periods of "thaw" and "reconstruction": "Year of the Dragon" is shot in 1981 (the premiere took place in 1982), followed by "Nozugum" film.

But, since our subject is "Creation of a Female Character in Works of Art of the Uighur Classics", in this section we will try to carry out the benchmark analysis of two afore-mentioned movies.

Both films are based on the historical events occurring on the territory of East Turkestan in the XIXth century.

The film represented the cinematography of the Republic of Kazakhstan (KazSSR) at two festivals and was noted by awards: at the XVth All-Union festival in Tallinn it was awarded the Jury Diploma "For development of a subject of the national liberation movement" and at the International forum of the countries of Asia, Africa and Latin America in Tashkent (A prize and the Diploma from the Uzbek Peace preservation committee). In the "New Film" magazine dated 1982, noting the success of "Kazakhfilm" in production of "Year of the Dragon" the 
author of the article, Sh. Shavayev writes that "The character of Askar, the teacher, played by Yu. Saitov, should be given special attention for his importance for subject development. The ideological leader of the insurgents, he embodies the national wisdom, ineradicable thirst for freedom. Not a single sophisticated persuasion or tortures can break it".

It is a well-known fact, that an actor's luck is first of all the merit of the director. This film has two directors: Asanali Ashimov and Tsoi Guk Ying. Their first meeting took place during shootings of the trilogy of movies "End of the Ataman", "Trans-Siberian Express", "Manchurian Option", based on A. Romov's story "Hokuman-hotel". A. Ashimov stars in the leading role of the scout Chadyarov. The third movie of the trilogy "Manchurian Option" is directed by I. Vovnyanko's and Tsoi Guk Ying.

The quality of I. Vovnanko's cameraman talent lies with aspiration to stay away from seclusion and force the viewer to empathize the internal state of heroes. Film's best shot scenes could be considered the attack and the ambush around fortress as well as the final scene - the execution of Maimkhan. The scale of the work can easily be felt throughout the shots of the galloping warriors during the attack at the fortress. In his camerawork, I. Vovnyanko accurately transfers the relation of the modern artist to the history of the Uighur people.

Let's notice that each of directors and actors of the movie "Year of a Dragon" managed to express the national character of the Uighur people, their spirit.

Thus, T. Yandiyeva, the performer of Maimkhan's role escalates this character to a high art level in the commonwealth with directors. Maimkhan-Yandiyeva - the freedom-loving, romantic person revolting against the Manchurian-Chinese aggressors and local feudal lords. However in lyrical episodes with Akhtam - she is a gentle, integral nature. One can read love in her eyes. And that love is saying she is ready to withstand all adversities, all deprivations together with him. But the main thing - to fight together for freedom of the people. Feeling her character in that way, the actress achieved the magnificent duet with the actor Oraz Amangeldyev playing Akhtam's part.

At the first sight, one can see many similarities between movies "Year of a Dragon" and "Nozugum": first, movies are shot in a traditional genre of the Soviet totalitarian film, based on traditions of historic-revolutionary movies. Secondly, the subject outline of the movie "Nozugum" does not correspond to the laws of film dramatic art, even though Helil Hamrayev, one of the Uighur classics of the XX century was the main consultant to the film. In our opinion, the movie was weaved from various sources and the imagination of screenwriters Abror Kosimov and Tamilla Kosimova.

From the very beginning of the movie, the plot develops promptly. Besides, the heroine Nozugum is constantly on the run. The viewer did not see the fighter but saw the "fugitive". The viewer can't quite understand where the action takes place, what year that is and the circumstances it is based on. The viewer will find it slightly difficult to understand the film if he is not acquainted with the actual legend of Nazugum.

In this film the art department recreated very interesting costumes of those years. But there is an impression that those were made with some negligence. It was a little weird to see the main character wearing same color costume all the time. Of course, the plan of designers seems clear: Nazugum's red dress semantically spoke about a lot - about blood shed by her people fighting for the liberation of the Homeland and about passion to justice. At some point, it seems that Nazugum tears her dress and takes out an identical dress from her bosom, although the extent of events does not allow us to think so. The troops of the Qin army did not differ, it was also strange to see different vestments on soldiers. Perhaps, the costume designer tried to show distinction in the rank in this way, but, in our opinion it was made clumsily.

Music and sound effects attracted special deal of attention. In this case, it could be the director's idea, however the sound department implemented it poorly for the mixed sound did not correlate to the visual sequence. Music seemed like an interesting one but it had some issues too. The idea seemed clear - musical acts made actors sing national songs by Nazugum and songs from the folk tales about her. The aspect that the music was not used with the national appeal- was ear-piercing. It was strange that musical aspects did not underline the national background of protagonists and antagonists since this could expose the plot better.

\section{Results}

On the basis of the scientific materials analysis and through the literary works of the Uighur classics and theatrical performances one can trace the history of an embodiment of legendary female images - heroines of the Uighur people. Ideological plans of performances are revealed. All this allowed enriching the theater palette. In article also provides the critical analysis in the course of studying of the embodiment of female characters in "Uzbekfilm" cinema. 


\section{Discussion}

Materials of article can be of interest to creators of theatrical, choreographic, musical and cinema art. It is possible to tell that this model of an inner world, bearing information on some events of the last centuries of the Uighur people.

Paying tribute to the classics of the Uighur literature such as Bilal Nazym, Ziya Samadi, to the composer K. Kuzhamyarov, and to all those who worked and created during their era, I would like to tell and quote words of the musicologist A. Mambetov: "Now, in the XXI st century, turning pages of the past, you feel deep respect for those who lived in that era and who sincerely worked, created and worried through the creativity of suffering and expectation of people of the Earth of those of years" (Mambetov, 2009, p. 27).

\section{Conclusion}

Thus, based on the above-studied materials, it is possible to note that the currently accumulated volume of unique historical information about lives of the well-known and outstanding Uighur women in works of poets, composers, theater and film directors solves a problem of reproduction of their characters in various genres musical, theater, and as well as in cinema.

Depicted by eyewitnesses and participants of events the destiny of legendary Iparkhan, Maimkhan, Nazugum, Rizvangul created a certain base for initiation of researches. The Heroic and Romantic elation of thinking reflecting a mental warehouse the Ili Uighurs was brightly demonstrated in national songs, legends, literary works by the classics of the Uighur literature - Bilal Nazym. He described grandiose revolt of the Uighur people of 1864-1867 in the poem "War of Muslims against Chinese", and in "A narration about Nazugum" he praised the heroine of the Uighur people the poetess Nazugum who preferred to die on the scaffold rather than surrender to conquerors (Nazym, 2011, p. 9).

It is known that in the period of the rule of a Manchurian dynasty Qin as a result of 1757-1760 war China managed to seize the territory of East Turkestan which was renamed into "Xinjiang" (in translation "New Land", "New line"). "The possession of Xinjiang as thought at the Manchurian administration, allowed giving vent to the "excess" population of China, to lift productive forces of Celestial Empire and, eventually, to strengthen domination of the Qin house" (Kuznetsov, 1973, p. 26). "The people underwent heavy economic, political and national oppression ... national economy degraded. All this could not but cause discontent of the people", points out the Tartar historian Nushirvan Yavushev who researched this region at the end of the XIXth century. (Ruziyev, 1982, p. 40). The armed march-offs of the Uighur population against the Chinese conquerors began in 1765. The first the city of Uch-Turfan rose, then disorders were spread to other cities. The insurgency was supported by the peasants. Conquerors brutally killed insurgents. Active armed forces "took Uch-Turfan by storm and, having killed all its population dead, they inspired terror into the entire people of Eastern Turkestan that the latter dared not to even attempt to overthrow of the Chinese oppression for the following 60 years", - the famous Russian scientist G. E. Grumm-Grzhimaylo wrote (Grumm-Grzhimailo, 1899, p. 122).

The big Chinese military contingent deployed at the new border of the Qin Empire, in the Ili region. The food for it was delivered from the South of East Turkestan. To provide the maintenance of army at a place, in 1760 the resettlement of the Uighurs from various oases and the cities (Kashgar, Hotan, Kuchar, Yarkand, Aksu, Uch-Turfan, etc.) began on these rough lands, which almost did not have settled population. The most active resettlement to the Ili region was carried out after the revolt suppression that allowed weakening the protest potential of the Uighur population in restless regions. Up to 80 settlements were created in new lands that combined the total population of about 12 thousand families consisting generally of poor people. The Manchurians called these immigrants "tarancha" ("farmers"). Besides farmery, the Uighurs of Ili region were used for other forced labor: they constructed irrigation canals, roads and fortresses, which gradually became settlements. This is how the cities of Suidongs, Old Ghuldja, New Ghuldja and others emerged.

The next large revolt of the Uighurs took place in 1825-1827. It began in Kashgar, then spread out to Yarkand, Yanysar and Hotan, but was suppressed, and the head of revolt Jahangir-hodzha was executed. In 1830 his elder brother Mad-Yusup-hodzha under the slogan "gazavata" (sacred war against the infidel) brought Kokand troops into East Turkestan. However the action was unsuccessful: due to hostile actions of the Bukhara emir, the Kokand khan was compelled to withdraw the army. Fearing the repressions, about 70 thousand of Uighurs moved in Kokand domain after these events: to the Syr Darya (south of Khodzhent), to the Dalvas district and near Tashkent where they founded Yanishar settlement.

The Uighur and Dungan population rebellion broke out in 1864 in the Ili region. Headed by the legendary Sadyr-palvan, after a long siege the insurgents took citadels of the cities of Bayangdai and Kura, and by the 
middle of 1866 they had already completely controlled the Ili valley. The Ili sultanate was formed - the state weak both economically, and politically, with the ruling clique torn apart by contradictions.

The imperial government was very much disturbed with the emergence of such unstable neighbor at the border with the lands recently annexed to Russia - the neighbor who would also be complicating the development of trade with the Western China. In June, 1871 the territory of the Ili region was occupied by the Russian troops without any resistance. Occupation proceeded within 10 years and, upon the whole, positively affected life of local population: the slavery and a number of feudal duties were abolished, taxes were lowered, local self-government was created, construction became more active, and the capitalist relations started developing. In 1881 Petersburg contract was signed between Russia and China according to which the government of China undertook to exempt participants of revolt "from personal and property responsibility". The population had a choice: "to remain in present residences in the Chinese citizenship" or "to be moved inside the borders of Russia and to become the Russian citizen" (Diplomatic thesaurus, 1985, pp. 378-379).

Prior to the beginning of 1884, 9572 Uighur families (about 45.4 thousand people) moved to Semirechye while only 2665 remained in the Ili region (Ruziyev, 1982, p. 71). Immigrants occupied the territories allocated for them and partially settled in the city of Verniy and its vicinities, and about 500 families chose Turkmenia as a new place of the accommodation founding the Bayram Ali settlement there. From Kashgaria they moved to the territory of modern Uzbekistan in the thirties of the XIXth century.

The valuable data accumulated by the great Kazakh scientist-orientalist Chokan Valikhanov give the chance to draw certain conclusions:

Despite the rigid restrictions imposed by Moslem doctrine in certain regions of East Turkestan in everyday life the Uighur women used certain freedom. He especially noted that at all severity of laws of Sharia in relation to the woman "it is necessary to refer the freedom of women who participate in all public meetings and even at the Medzhilis assemblies to a number of the good sides of Kashgar character" (Valikhanov, 1985, p. 192). Describing position of women of the Kashgar region and seven cities, Ch. Valikhanov wrote: "... Turkestanis of Seven cities (Kumul, Turfan, Karashar, Kuchi, ... Aksu, Yarkand, Kashagar) - the people are ultimately free... Being Muslims ... they do not hide women" (Valikhanov, 1985, p. 280).

Therefore and in the first place, the incarnation of national wisdom and ineradicable thirst for freedom was represented by actresses, playing leading roles: Iparkhan, Maimkhan, Nazugum. They were not broken by either sophisticated persuasions or tortures.

\section{References}

Abikeeva, G. (2006). National Building in Kazakhstan and other countries of the Central Asia and how the process reflected on the Cinemas. Almaty: Social Fund "CCAC".

Almas, T. (2008). Uighurs. Almaty: Mir.

Diplomatic thesaurus: In 2 Parts. Part 2. (1950). Moscow.

Ganichev, V. (2011). In M. Khamrayev (Ed.), The Never-dying Word of Centuries (foreword). Comp.: Kh. Khamrayev. Almaty: Mir.

Grumm-Grzhimailo, G. (1899). Description of a journey to the Western China, Part 2. St. Petersburg.

Gumilev, L. (1993). Ancient Turks. Moscow: Partnership "Klyshnikov, komarov and Co".

Kadyrova M. (1983). The selected lyrics of the East: Zebunnisa, Dilshod, Anbar-Atyn. Tashkent.

Khamrayev, M. (1996). The Never-dying Word of Centuries. Almaty.

Khasanova, R. (1986). The processes of establishment and development of the Uighur musical drama. Synopsis of a thesis, Tashkent, Art Studies Institute named after Khamza.

Kirina, K. (1994). Kuddus Kuzhamyarov and the Uighur musical culture. Almaty.

Kirina, K., \& Khasanova, R. (2003). The life and art way of K. Kuzhamyarov. I am lucky to be the first one in destiny. Composer Kuddus Kuzhamyarov. Collection of articles, thoughts and memories. To the 85th anniversary of composer's birthday. Almaty: Center Print.

Kuznetsov, V. (1973). Economic politics of Qin government in Xinjiang in the first half XIX century. Moscow.

Mambetov, A. (2009). Historical Ballet of Gaziza Zhubanova "Hiroshima". Kazakhstan balet alemi, 1(2).

Nazym, B. (2011). Selection. Almaty: Mir. 
Nemenskiy, B. (1987). The Wisdom of Beauty. Moscow: Prosveschenie.

Pantusov, N. (1881). The war of the Muslim against the Chinese (1st ed.). Kazan.

Pantusov, N. (1909). The samples of the Taranchi national literature. Kazan.

Rakhmanaliyev, R. (2013). Turk Empire. History of the Great Civilization. Moscow: Ripol Classic.

Ruziyev, M. (1982). The Newborn Uighur Nation. Alma-Ata.

Saitova, G. (2011). The Uighur scenic dance (based on the material of plays and concert shows of Uighur Theater in Almaty). PhD thesis, Almaty, Institute of Literature and Art named after M. Auezov.

Saitova, G. (2011). Uighur Dance: The Origins. Traditions. Scenic performance. Almaty: Mir.

The Great Encyclopedia (2nd ed., revised and enlarged). The Great Russian Encyclopedia. (1998). Moscow.

Valikhanov, Ch. (1985). Western region of the Chinese empire and Ghuldja city. Ghuldja trip diaries. 1856 year. Collected works: in 5 Parts. Part 2. Alma-Ata.

Yurenev, R. (1986). The Novice of Soviet Film art: Book for the teacher. Moscow: Prosveschenie.

\section{Copyrights}

Copyright for this article is retained by the author(s), with first publication rights granted to the journal.

This is an open-access article distributed under the terms and conditions of the Creative Commons Attribution license (http://creativecommons.org/licenses/by/3.0/). 